\title{
Landslide Risk Assessment of the Patlekhet Landslide in Myagdi District, Nepal
}

\author{
Basanta Raj Adhikari', Naresh Nidal, Bhupendra Kumar Yadav, Surendra Awasthi \\ Department of Civil Engineering, Pulchowk Campus, Institute of Engineering, Tribhuvan University, Nepal \\ 'Corresponding author: bradhikari@ioe.edu.np
}

Received: Jan 22, $2017 \quad$ Revised: March 30, $2017 \quad$ Accepted: April 5, 2017

\begin{abstract}
Nepal Himalaya is one of the most active mountain belts with several kilometers of relief which is very prone to catastrophic mass failure and this region encounter the problem of landslide almost every year during monsoon period causing large scale of devastation. Most of the landslides are caused by river bank erosion, monsoon and earthquakes. Patlekhet landslide, Myagdi district represents the vulnerable condition of the hilly region and therefore it is chosen for study. Hydro-meteorological analysis of the landslide including estimation of the physical characteristics of the landslide and different parameter were used for the study. The Thiessen polygon and arithmetic average methods are used for rainfall analysis of the landslide and high flood level is estimated at the toe of the landslide. The risk is calculated by assessing the vulnerability of different exposure elements such as population, households, agricultural land and water supply through the use of quantitative tools and techniques. It is clear that the landslide was triggered by heavy rainfall and toe cutting by Raghu Ghat Khola. Around fourteen percent households' lie in the high risk zone and others are in moderate and low risk zone. The level of risk is changing every year with increasing number of population and continuous movement of landslide.
\end{abstract}

Key words: Landslide, vulnerability, risk analysis

\section{Introduction}

Landslide in Nepal's hill is the major cause of huge loss of life and property every year, at the same time huge amount of debris flow takes place which ultimately gets deposited in the plain and fertile land of Terai and cause blockage of river flow causing flood. Due to unique altitudinal variation within the short horizontal distance and unstable and seismically active geographic condition of hilly region makes it more prone to mass failure every year especially in monsoon period. River toe cutting, heavy rainfall and steep slope of the mountains are mainly responsible for hill slope movement. Most of the villages in the Nepalese mountains are situated in and around the old landslide, which clearly indicates the landslide vulnerability of the mountainous people. People are facing landslide risk in daily life because of inadequate development planning and unscientific investigation. Therefore, proper scientific investigation should be carried out to address these challenges in the mountainous slope because it is the first step to understand the hill slope dynamics in such terrain. It explains about the probability of occurrences of failure and its effect to 
the community. Government as well as community has started to mitigate such kinds of hazard to reduce the risk however all the stabilization works did not last long. Reducing risk without proper investigation is only waste of resources. To address this problem, Patlekhet landslide, Patlekhet VDC, Myagdi district is chosen for the study (Fig. 1). The Patlekhet landslide is situated just below the Patlekhet village and slowly taking away the material to the Raghu Ghat Khola.

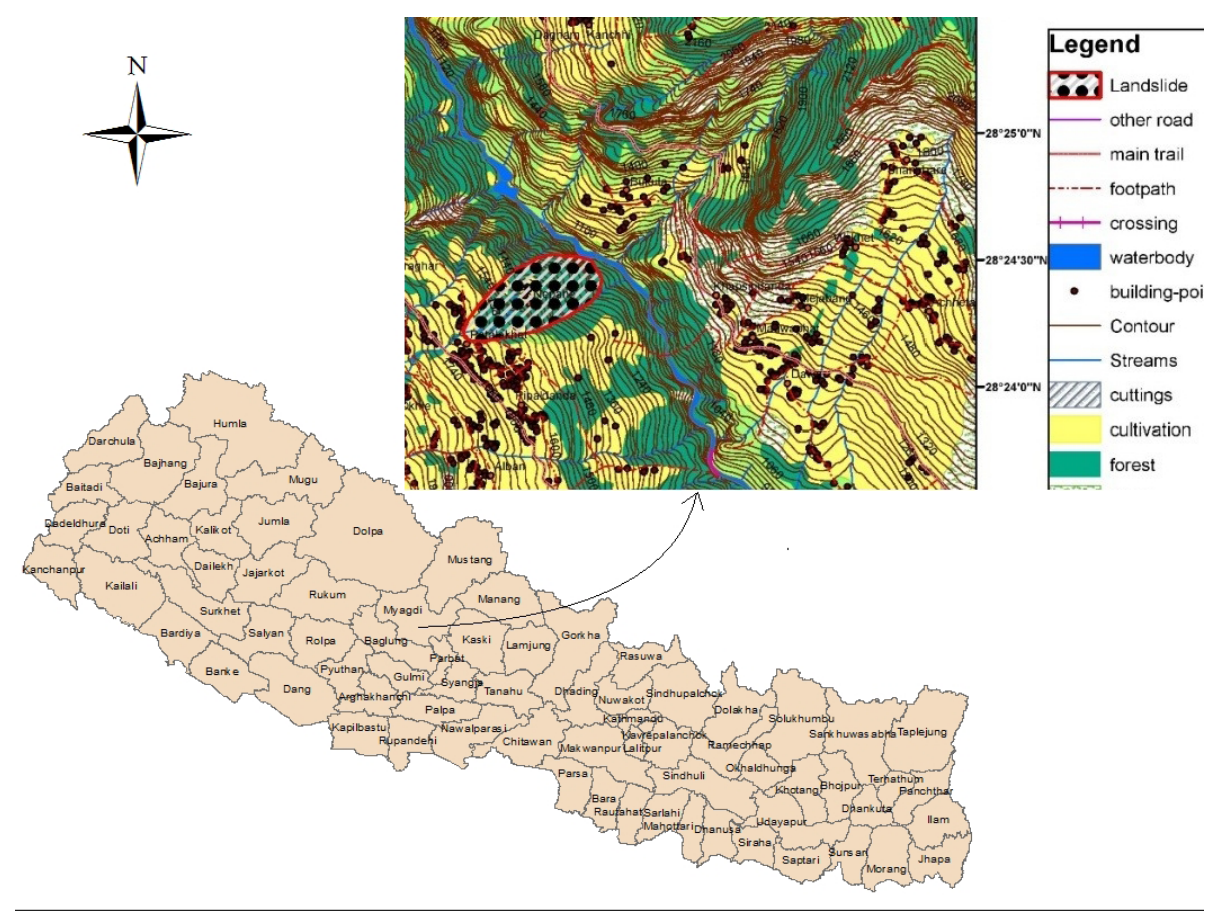

Fig. 1: Land use Map of the Patlekhet VDC, Mayagdi district

This study has explained the overall scenario that how continues the cutting of underneath river leads to risk of landslide in upper part. Moreover, this study reflects the sensitivity and risk perception of the settlement along with the need of mitigations major against probable disaster.

\section{Methodology}

Quantitative as well as qualitative method with field based discussion and verification approaches have been used for this study. Data collection of risk elements, hydrological parameters had done before and during field visit which was supported by walk-over survey with focus group discussion and interview with local people about historical background and existing hazard profile. Global Positioning System (GPS) points of the landslide are then transferred and interpreted in ArcGIS 10 platform. The detail methodology of the study is described in following sections.

\subsection{Hydro Metrological Analysis}

The daily rainfall data from 1994-2013 AD of the three rainfall stations (Kuhun, Beni Bazar and Bega) nearby of the study area are selected for the rainfall analysis [2]. The daily rainfall data are then summed to calculate the average annual rainfall for the 20 years. Arithmetic average and Thiessen polygon methods are used to calculate the annual as well as monsoon rainfall. The daily discharge data (1990-2010 AD) of Myagdi khola at Mangalaghat are collected from Department 
of Hydrology and Meteorology (DHM), Government of Nepal. The discharges data are then transposed at the toe end of the landslide by using the Catchment Area Ratio method (CAR). The catchment area ratio at the toe end of the landslide is 0.2949 (i.e. 328/1112). The extreme discharges of every year are used for flood frequency analysis using Gumbel's method for different return year period. The High Flood Level at the toe is calculated by using the rating curve which is generated using Manning's equation.

\subsection{Landslide Movement Analysis}

Landslide movement analysis is done by using Google Earth images and interview with local senior citizens. The Google Earth images are mostly analyzed to see the changes in landslide dimensions and directions (Fig. 2). This analysis clearly reflects the condition of the landslide and its advancement year by year which clearly shows the advancement of the landslide towards right top corner of the landslide.

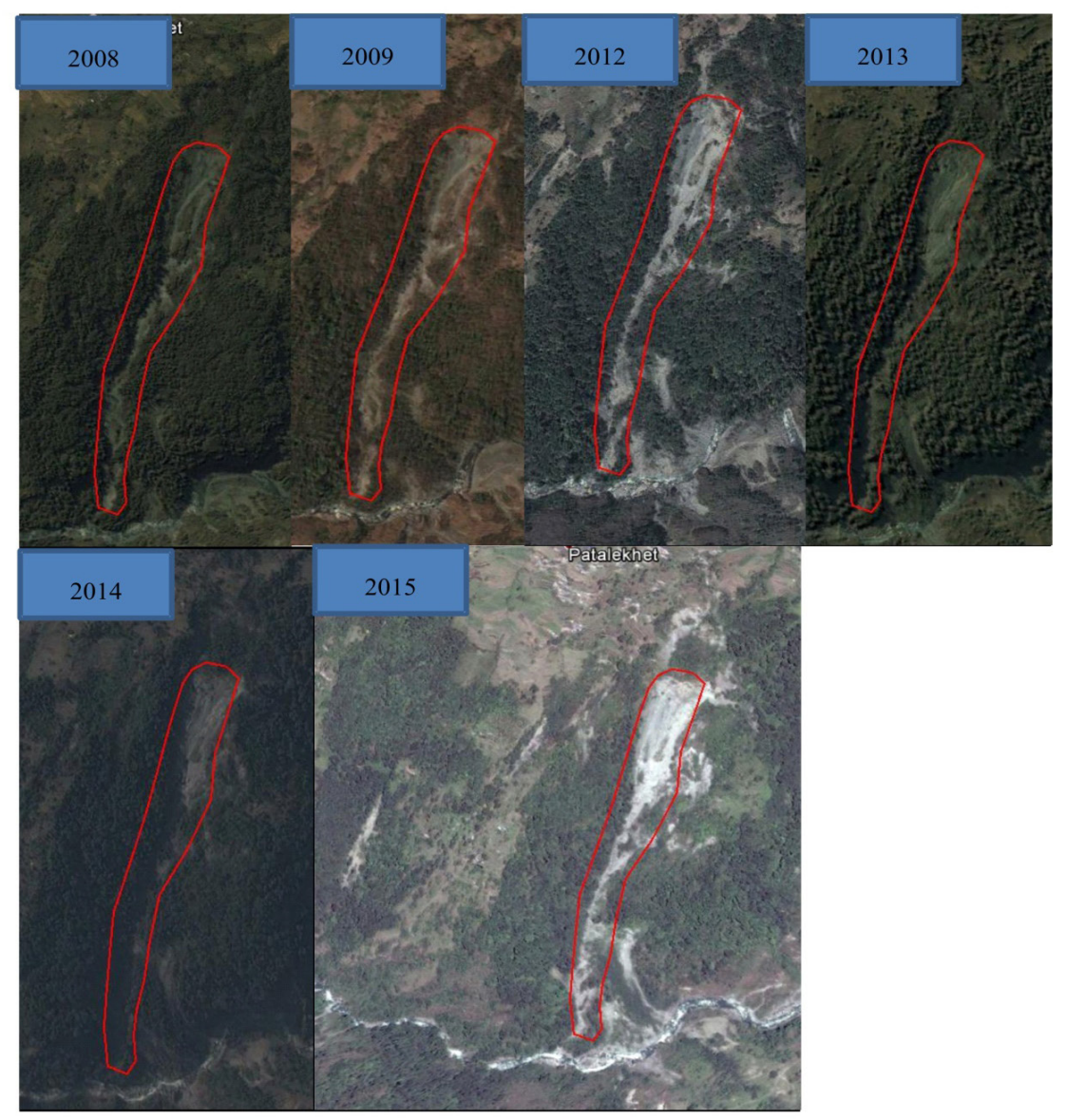

Fig. 2: Google Earth Image of Landslide to show the changes year by year

\subsection{Hazard Analysis}

The method developed by Nadim et al. [3] is adopted for hazard analysis. The landslide hazard indices were estimated using the equation: $\mathrm{Hr}=\left(\boldsymbol{S}_{r} \times \boldsymbol{S}_{i} \times \boldsymbol{S}_{h} \times \boldsymbol{S}_{v}\right) \times \boldsymbol{T}_{p}$ 
where, $H_{r}$ is landslide hazard index for rainfall induced landslide,

$S_{r}$ is the slope factor within a selected grid,

$S_{i}$ is the lithological (or geological) conditions factor,

$S_{h}$ is the soil moisture condition, $\mathrm{T}_{\mathrm{p}}$ is the precipitation factor

$S_{v}$ describes the vegetation cover

The different indices are calculated for the study area with reference to different published articles and field data collection.

\subsection{Vulnerability Analysis}

Weighted overlay method $[1,4,6,5]$ is adopted for this study where each parameter and zone are assigned by certain index weightage on the basis of its relative importance and its damaging effects. The study area is divided into four zones ( Zone - I, II, III, IV) with radius of $200 \mathrm{~m}, 400 \mathrm{~m}, 800 \mathrm{~m}$ and $1200 \mathrm{~m}$ from the center of the landslide in the GIS platform (Fig. 3). All the exposure elements (population, land, and water supply, household) are then analyzed considering those zones.

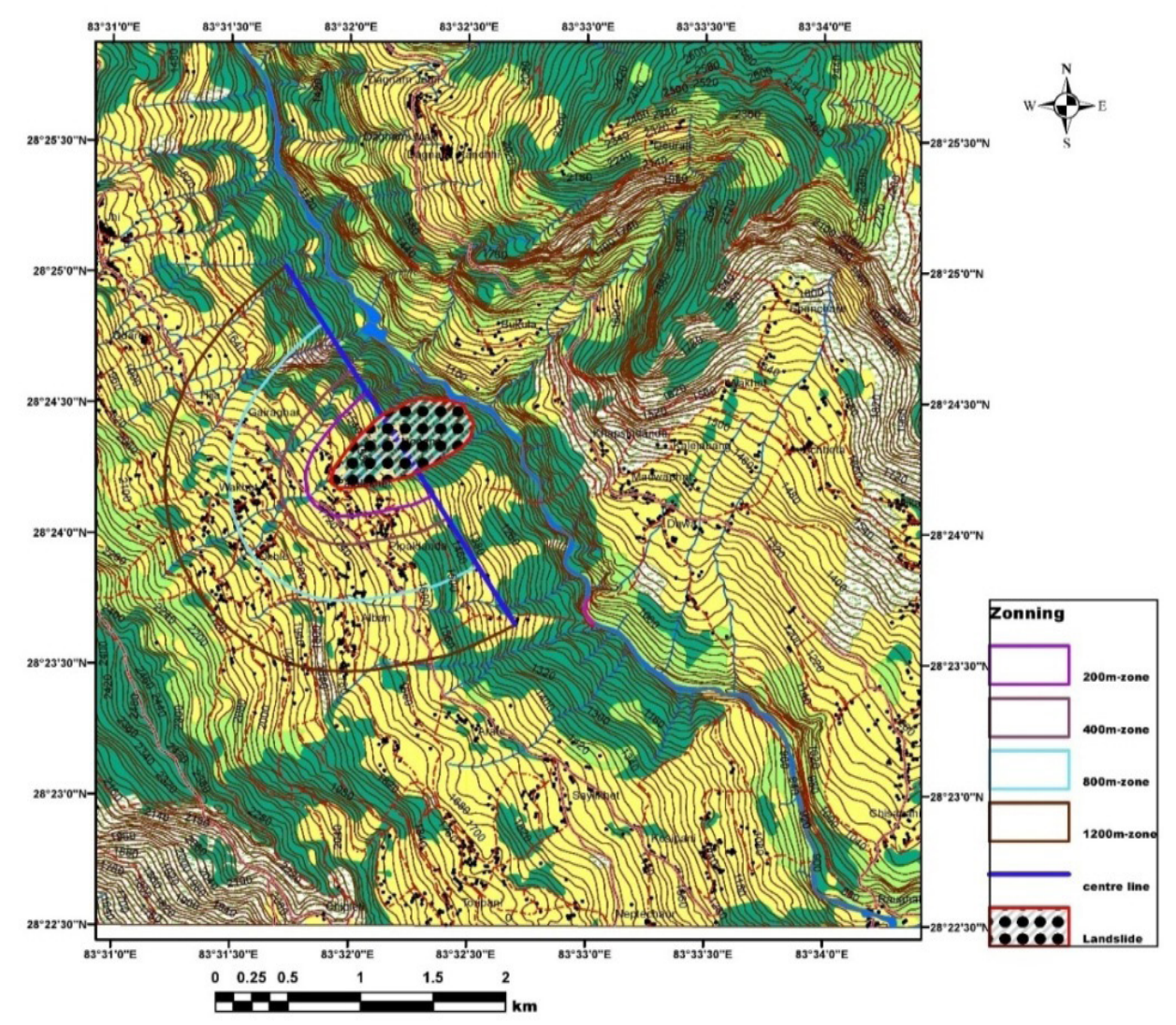

Fig. 3: Division of Zones of Patlekhet VDC at Risk

The ranking values are ranging from 10 to 50 and nearer to the landslide are assigned the highest value and accordingly the lowest value to the farthest. After calculating the number and quantity of exposure elements in each zone the vulnerability factor for each exposure elements are redistributed. 
Linear distribution method is adopted to redistribute the assigned vulnerability factor (Table 1, 2 and 3).

Table 1 : Vulnerability factor for Population

\begin{tabular}{|l|l|l|l|l|}
\hline \multicolumn{5}{|l|}{ Individual Vulnerability factor } \\
\hline Zone & Zone-I & Zone-II & Zone-III & Zone-IV \\
\hline Max Range & $\mathbf{5 0 - 4 0}$ & $\mathbf{4 0 - 3 0}$ & $\mathbf{3 0 - 2 0}$ & $\mathbf{2 0 - 1 0}$ \\
\hline$<5$ yrs./ Male & 5.66 & 4.59 & 2.94 & 2.00 \\
\hline$<5$ yrs./ Female & 4.45 & 3.92 & 2.89 & 1.89 \\
\hline $6-10$ yrs./ Male & 8.12 & 5.55 & 3.03 & 1.99 \\
\hline $6-10$ yrs./ Female & 5.06 & 4.24 & 3.39 & 2.32 \\
\hline $11-15$ yrs./ Male & 3.30 & 3.28 & 3.93 & 2.35 \\
\hline $11-15$ yrs./ Female & 5.29 & 4.71 & 3.58 & 2.32 \\
\hline $16-24$ yrs./ Male & 7.84 & 6.11 & 4.35 & 2.66 \\
\hline $16-24$ yrs./ Female & 6.69 & 5.23 & 4.85 & 3.31 \\
\hline $25-45$ yrs./ Male & 11.88 & 8.93 & 5.51 & 3.19 \\
\hline $25-45$ yrs./ Female & 15.16 & 10.64 & 6.28 & 4.10 \\
\hline $45-60$ yrs./ Male & 3.90 & 3.21 & 2.66 & 1.15 \\
\hline $45-60$ yrs./ Female & 5.76 & 4.71 & 3.74 & 1.83 \\
\hline $60-75$ yrs./ Male & 3.06 & 2.20 & 1.36 & 0.95 \\
\hline $60-75$ yrs./ Female & 4.007 & 2.80 & 1.58 & 1.12 \\
\hline$>75$ yrs./ Male & 1.47 & 1.23 & 0.84 & 0.35 \\
\hline$>75$ yrs./ Female & 0.86 & 1.11 & 0.91 & 0.33488 \\
\hline Total Factor & $\mathbf{9 2 . 5 8}$ & $\mathbf{7 2 . 5 3 5 0 5}$ & $\mathbf{5 1 . 9 1}$ & $\mathbf{3 1 . 9 3}$ \\
\hline
\end{tabular}

This table shows the individual value linearly interpolated within the respective maximum range of value indicated above depending upon the age of the population for the different wards in the difference range. The values are assigned to population as well as household variables according to age and types of roof (child and old age are given higher values as they are more vulnerable and as done for type of roof). All the values are summed up to get total value for the population as one of the major exposure of vulnerability. Similarly, Vulnerability factors for water supply and household are also calculated and values of individual exposure elements are finally summed up to get the value of overall vulnerability factor.

Table 2: Vulnerability Factor for Water supply

\begin{tabular}{|l|l|l|l|l|}
\hline \% house hold affected & Zone-I & Zone-II & Zone-III & Zone-IV \\
\hline Zone & 41.0 & 51.0 & 137.0 & 140 \\
\hline Total affected & 485.0 & 485.0 & 485.0 & 485.0 \\
\hline Grand Total present & 8.45 & 10.51 & 28.24 & 28.86 \\
\hline \% affected & & & \\
\hline
\end{tabular}


Table 3: Vulnerability Factor for Household

\begin{tabular}{|c|c|c|c|c|c|}
\hline \multicolumn{6}{|c|}{ Individual Vulnerability factor } \\
\hline & Zone & Zone-I & Zone-II & Zone-III & Zone-IV \\
\hline \multirow{6}{*}{$\begin{array}{l}\text { Types of } \\
\text { Roof }\end{array}$} & Max. Range & $50-40$ & $40-30$ & $30-20$ & $20-10$ \\
\hline & Food Residue & 13.78 & 2.60 & 4.85 & 0.32 \\
\hline & GI sheet roof & 73.41 & 14.28 & 16.13 & 2.24 \\
\hline & Stone Roof & 3.99 & 0.69 & 1.16 & 0.07 \\
\hline & $\mathrm{RCC}$ roof & 0 & 0 & 0 & 0 \\
\hline & Total & 91.19 & 17.57 & 22.15 & 2.65 \\
\hline
\end{tabular}

\subsection{Risk Analysis}

Risk is determined by three components: hazard, element at risk and vulnerability. In this study, risk refers the degree of loss of live, households, water supply and agricultural land. The risk is calculated by multiplying hazard and vulnerability with this relation: Risk=Hazard *Vulnerability. The range of risk is depends upon the level of damaging effect that it can cause the physical elements (Table 4).

Table 4: Risk range with its types

\begin{tabular}{|l|l|l|l|}
\hline S.N & Range & Type & Remarks \\
\hline 1 & $\mathbf{0 - 2 5 0}$ & Low & \\
\hline 2 & $\mathbf{2 5 0 - 5 0 0}$ & Moderate-High & \\
\hline 3 & $>\mathbf{5 0 0}$ & Very High & \\
\hline
\end{tabular}

\section{Result and Discussion}

\subsection{Physical Characteristics of the Landslide}

The Patlekhet landslide is a rotational type landslide of having 27 degree of average slope. The length of the landslide is $1003 \mathrm{~m}$ and the average width is $400 \mathrm{~m}$ covering of 42 hectare areas (Fig. 4). Geologically, the landslide lies in the lesser Himalaya consisting for highly weathered phyllite with quartz vein. Multiple sharing mechanism and consolidation with seeping made slope rock jointed and rock mass became chemically weathered. Due to increase of the pore water pressure the displaced material also became unstable. Furthermore, the rain is percolating from the tension cracks and the holes formed by the activity of the different animals having shelter inside earth by making hole. The transported material is deposited in the middle of the landslide just above the steep slope (Fig. 4). 


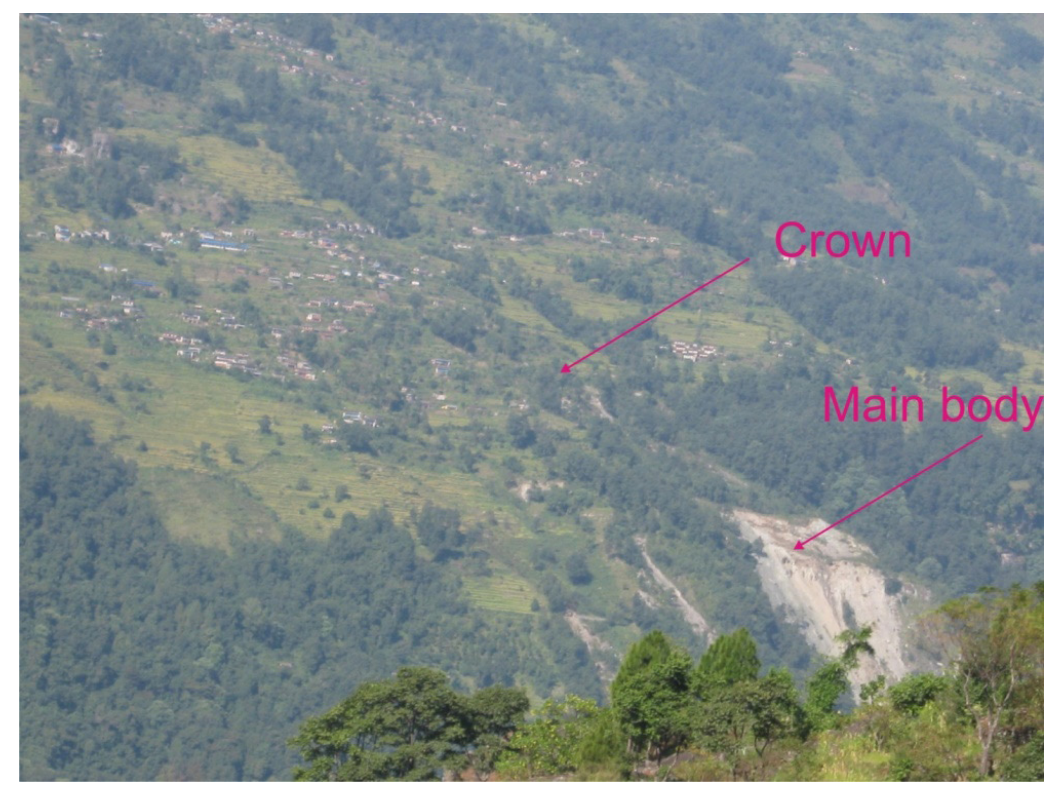

Fig. 4: Overview of the landslide

The debris flow within the landslide eventually causes the formation of deep gulley. Highly weathered phyllite is exposed at the toe of the landslide. The attitude of the foliation plane is $251^{\circ} / 24^{\circ}$ (Dip direction/dip amount) and natural slope is $60^{\circ} / 35^{\circ}$ (Dip direction/dip amount).

\subsection{Hydro-metrology}

The total watershed of the study area is $1.23 \mathrm{sq} . \mathrm{km}$. The long term average annual rainfall of the project area as calculated from Arithmetic mean method is $1739.97 \mathrm{~mm}$ and monsoon rainfall is $1369.87 \mathrm{~mm}$. Similarly the long term average annual rainfall of the project area as calculated from Thiessen polygon method is $1717.13 \mathrm{~mm}$ and the monsoon rainfall is $1353.83 \mathrm{~mm}$. The average monsoon rainfall of all the three stations were averaged and plotted for the project site (Fig. 5).

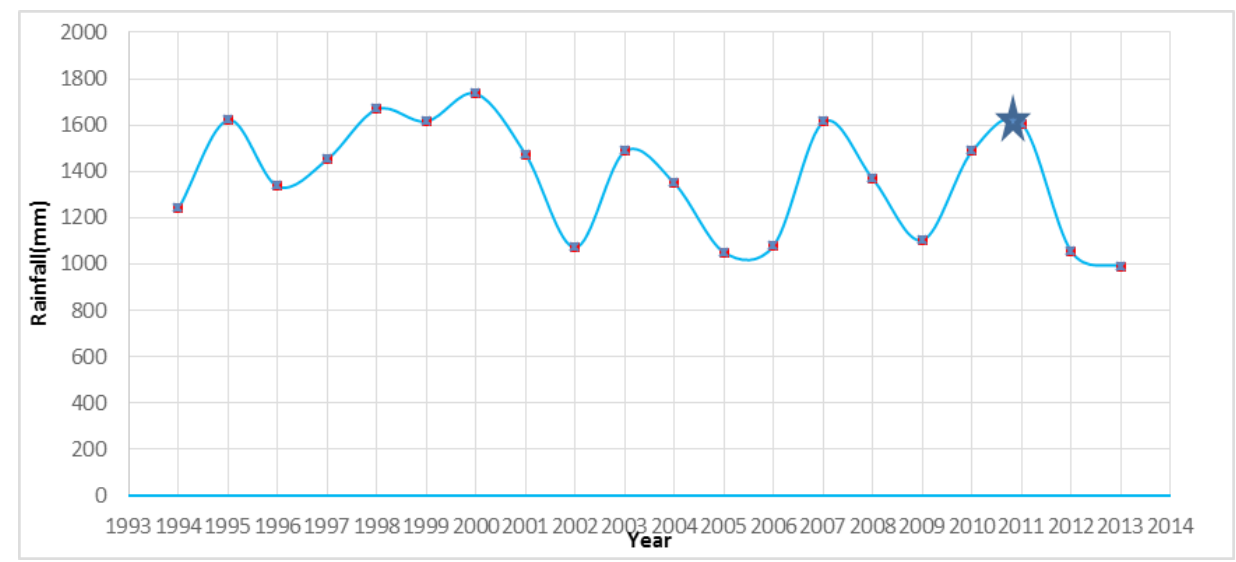

Fig. 5: Monsoon Rainfall of Patlekhet Area 
The landslide was very active in 2011 and destroyed many properties especially cultivate land. This event also supported by the rainfall data (Fig. 5), Google Earth and local people information (Fig. 6). This is due the continuous flood event in the Raghu Ghat Khola. The food event was very high in 2009 and it is clear that there should have been a notable toe cutting in the khola (Fig. 7).

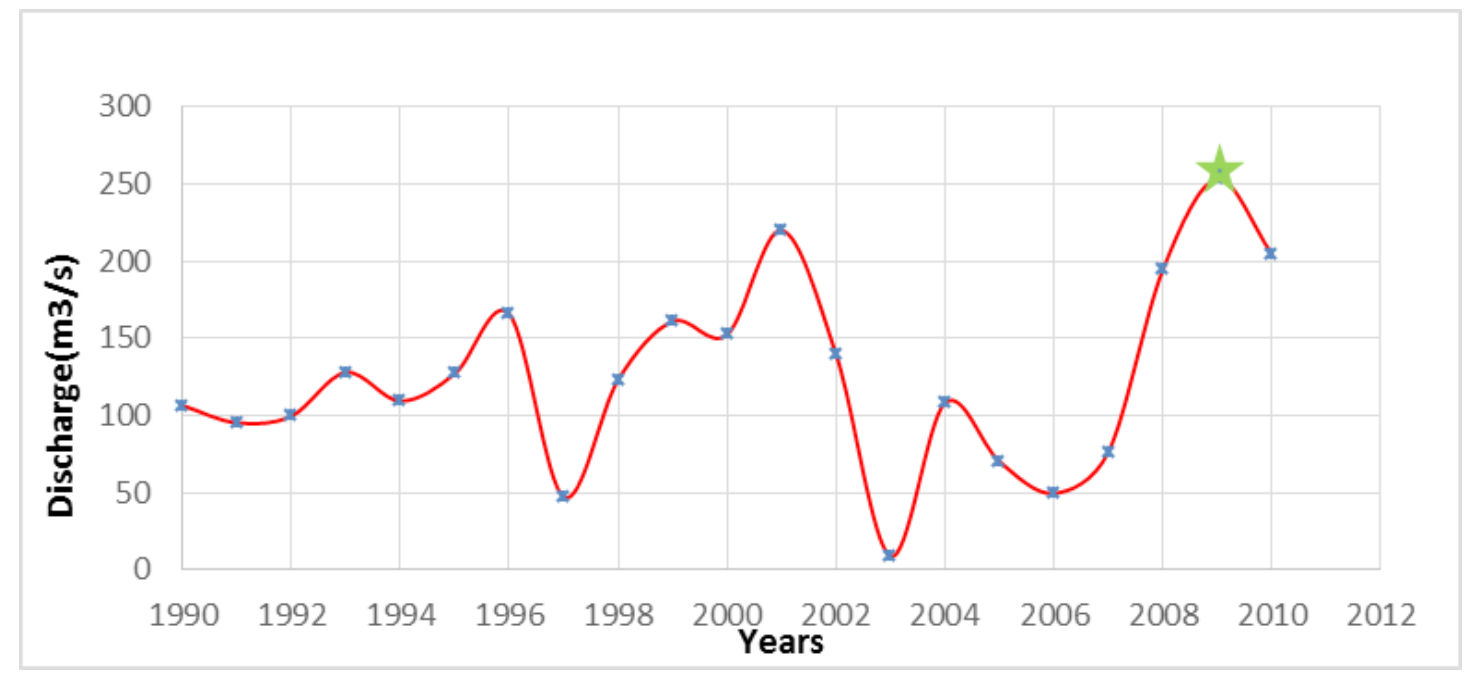

Fig. 6: The river discharge of the Raghughat Khola

This toe cutting is also supported by the high flood level at the toe of the landslide in the Raghu Ghat Khola is $3.3 \mathrm{~m}$ from the bed level i.e. $1090.05 \mathrm{~m}$ in 2009 (Fig. 8 and 9).

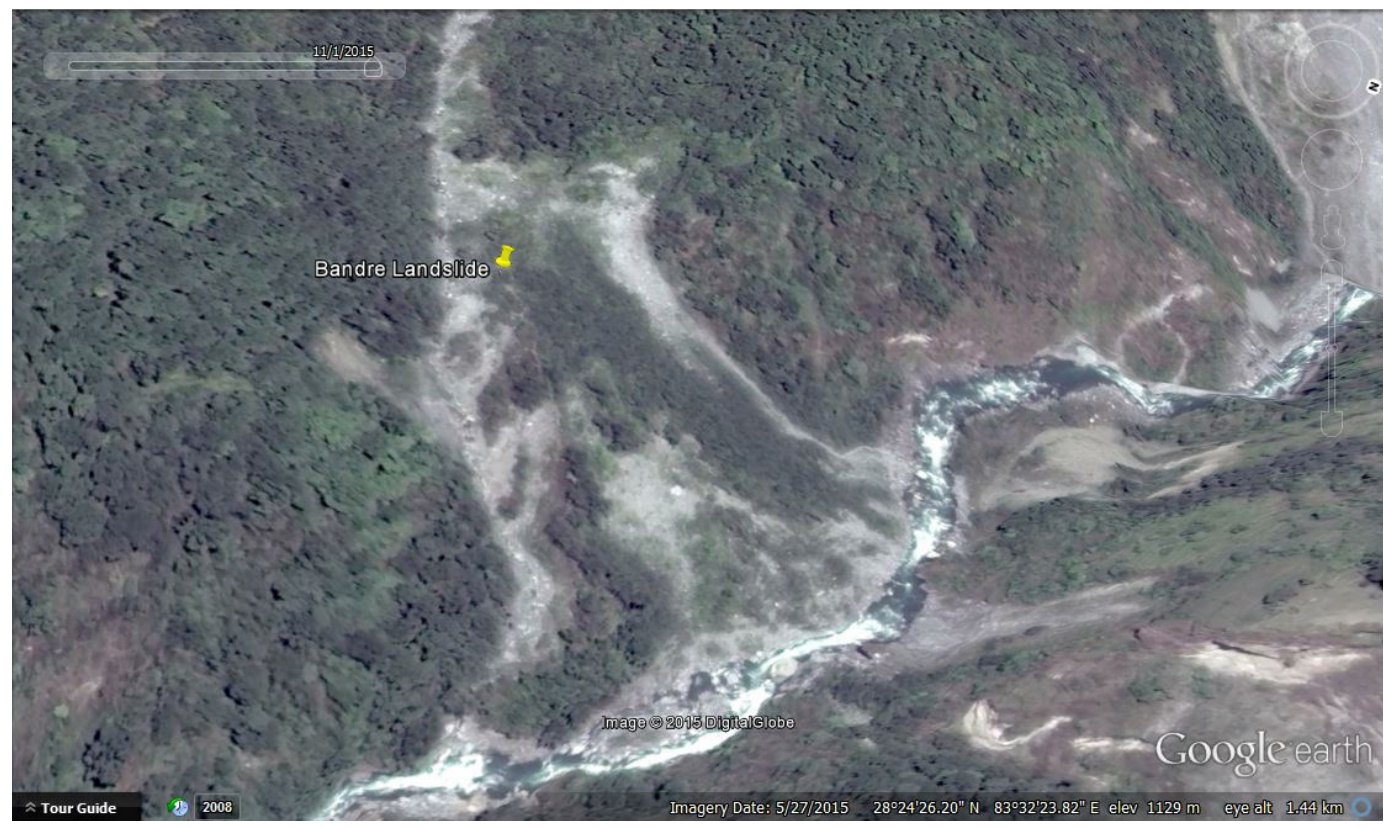

Fig. 7: River toe cutting by Raughat Khola 


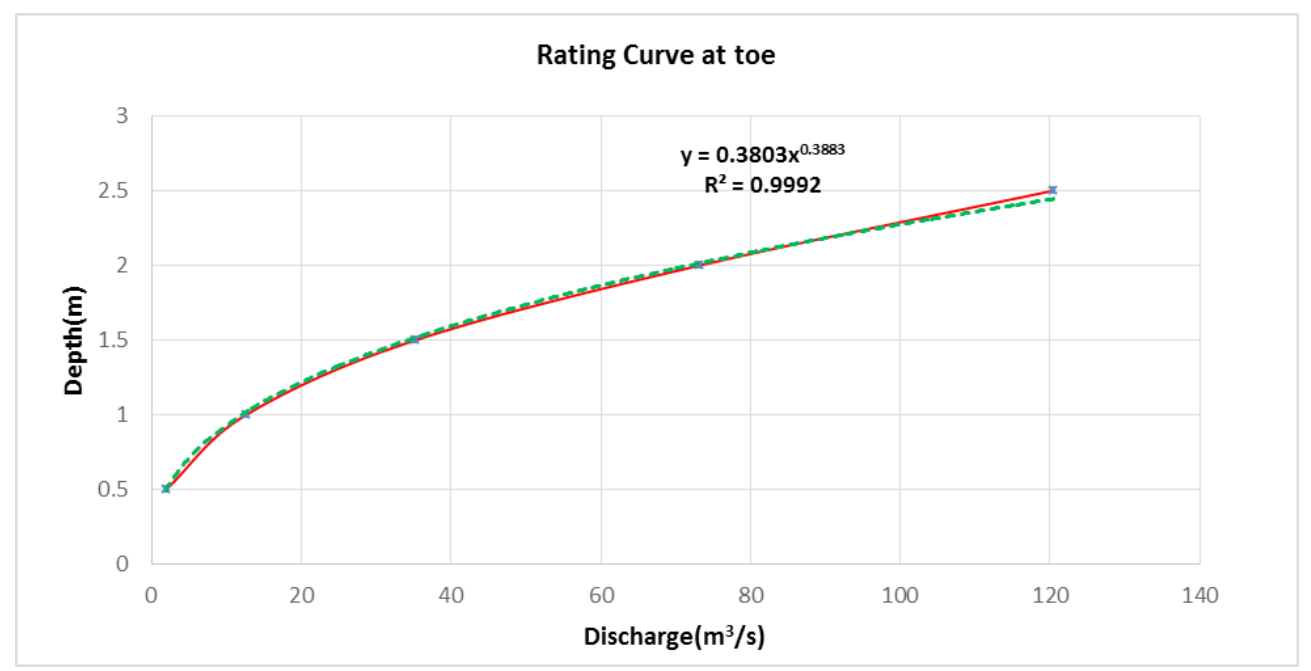

Fig. 8: Rating curve used for flood level calculation

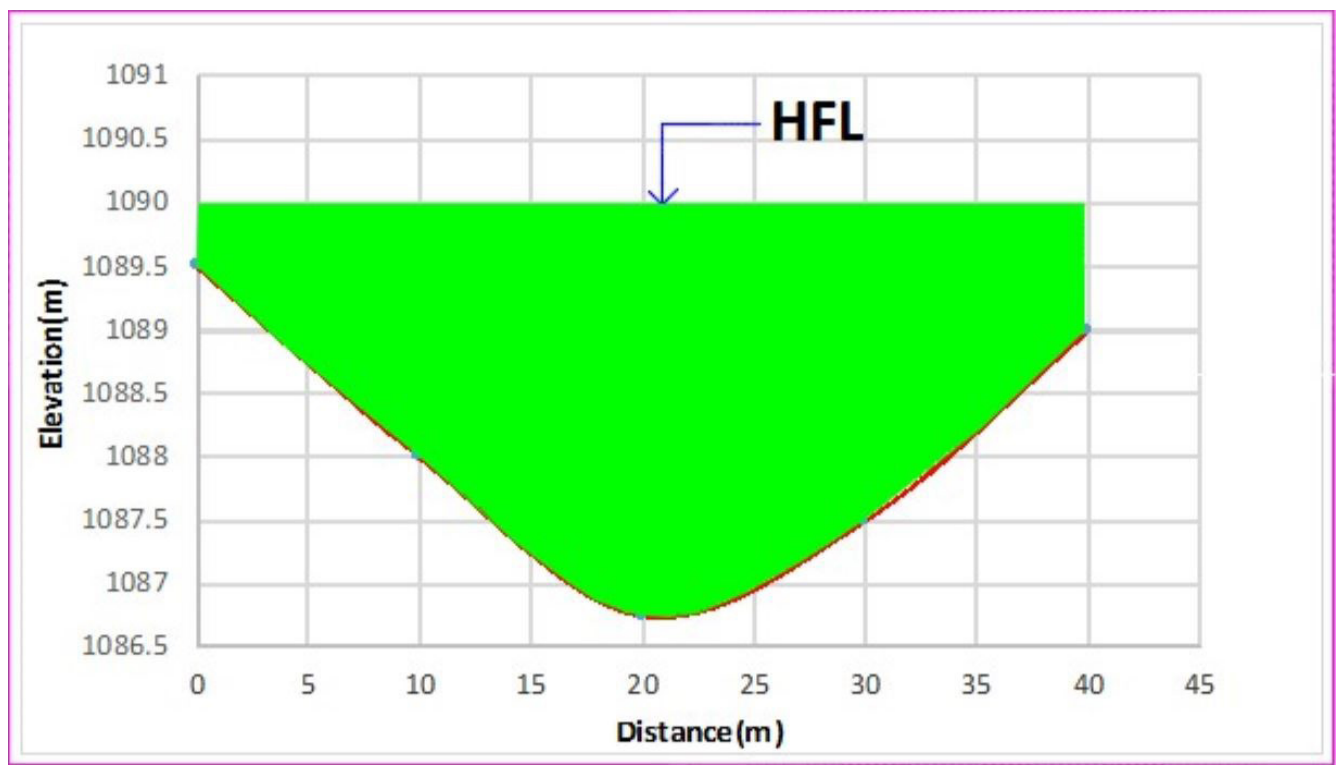

Fig. 9: High flood level calculation

\subsection{Hazard}

The landslide hazard index (LHI) is calculated based on Nadim et al. [3]. The value for each and individual factors are calculated by using standard chart proposed by Nadim et al. [3]. The average slope of the landslide is 27 degree. Hence the value for slope factor is 5. Lithological factor of the landslide is 3 because of having phyllite and quartzite. Soil moisture indicates the mean humidity throughout the year and gives the indication of the soil prior to the heavy rainfall and destabilization. A reference table is generated by the Climate Prediction Centre [7] as presented below to find the corresponding value of the moisture factor. From the hydrological analysis the corresponding soil 
moisture factor is 2 . The vegetation cover index of the areas fall in the category $1[8]$. The Precipitation Triggering Index $\mathrm{Tp}$ is $6 \mathrm{~m}$ which is calculated based on the estimation of the 100-year extreme monthly rainfall and anomaly factors for precipitation. Therefore, the Patlekhet landslide fall under the category of high hazard potential having 180 (LHI) (Table 5) [3]. The hazard is then divided into three types namely Low, Moderate and High giving hazard factors 1, 2 and 3, respectively.

Table 5: Physical Characteristics of Patlekhet Landslide

\begin{tabular}{|l|l|l|l|}
\hline S.N & Factors & Value & Remarks \\
\hline 1 & Slope factor & 5 & \multirow{2}{*}{ from the analysis } \\
\cline { 1 - 2 } & Lithological factor & 3 & \\
\hline 3 & Soil moisture factor & 2 & \\
\hline 4 & Vegetation cover & 1 & \\
\cline { 1 - 2 } 5 & Precipitation triggering factor & 6 & \\
\cline { 1 - 2 } & Landslide hazard index $=$ & $\mathbf{1 8 0}$ & \\
\hline
\end{tabular}

\subsection{Vulnerability}

The total vulnerability is calculated for individual zones by adding the individual vulnerability factors (Table 6). Based on the vulnerability values obtained from the calculation, the index are defines as Very High, High, Moderate and low. Zone I is very high vulnerability index because of vulnerable roofs and individual vulnerability whereas zone II has low because of low number of vulnerable houses and affected household. The zone IV lies very far from the landslide however it has moderate vulnerability because of high percentage affected household in combination with individual vulnerability.

Table 6: Total vulnerability for individual zones

\begin{tabular}{|c|c|c|c|c|}
\hline \multicolumn{5}{|l|}{ Total Vulnerability } \\
\hline & Zone-I & Zone-II & Zone-III & Zone-IV \\
\hline Types of Roof & 91.2 & 17.6 & 22.2 & 2.7 \\
\hline Affected household percent & 41 & 51 & 137 & 140 \\
\hline Individual vulnerability & 92.6 & 72.5 & 51.9 & 31.9 \\
\hline \multirow[t]{2}{*}{ Total } & 224.8 & 141.1 & 211.1 & 174.6 \\
\hline & Very High & Low & High & Moderate \\
\hline
\end{tabular}

\subsection{Risk Profile}

The risk value for different zone is different due to having the different scale of exposure elements e.g., Population, household and individual vulnerability, see Table 7 and Fig. 10. The zone II has moderate risk whereas other zones are in high risk due to landslide. It is clearly seen that most of the Patlekhet lies in the high risk zone. The reason for high risk is due to high vulnerability index because the hazard level is same for all zones. 
Table 7: Risk Profile

\begin{tabular}{|l|l|l|l|l|}
\hline \multicolumn{4}{|l}{ Risk Calculation } \\
\hline & Zone-I & Zone-II & Zone-III & Zone-IV \\
\hline Hazard & 3 & 3 & 3 & 3 \\
\hline Vulnerability & 224.8 & 141.1 & 211.1 & 174.6 \\
\hline Risk & 674.3 & 423.3 & 633.2 & 523.8 \\
\hline & High & Moderate & High & High \\
\hline & & & & \\
\hline
\end{tabular}

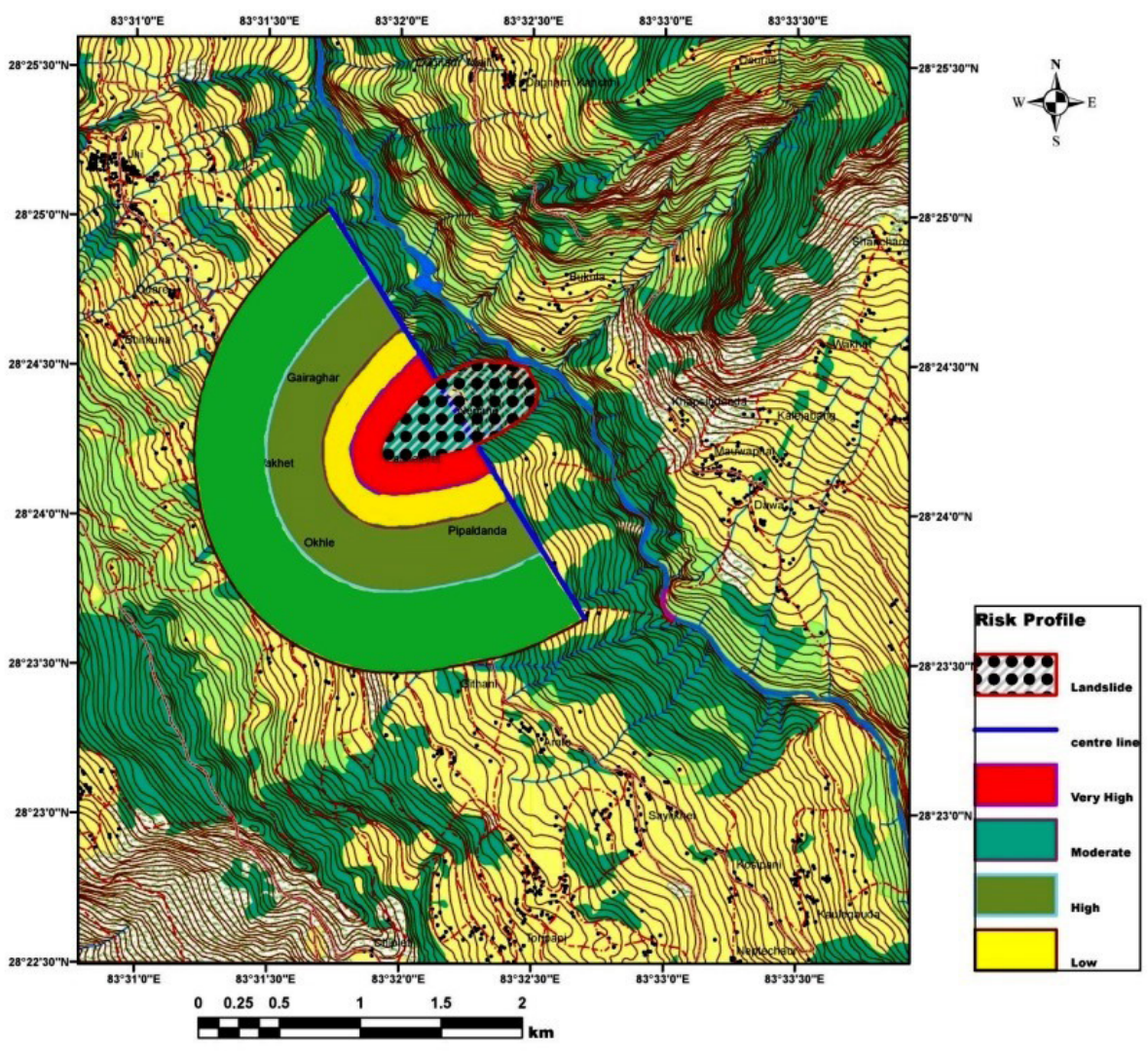

Fig. 10: Risk Zonation of Patlekhet landslide

\section{Conclusion and Recommendations}

The landslide risk assessment in the Patlekhet landslide has provided a unique opportunity to understand the risk associated with mountain villages. Patlekhet landslide is triggered by heavy rainfall and river toe cutting. The whole village lies in the high hazard zone based on slope, rock type, soil moisture and precipitation. Types of house roof, affected housed percentage and individual vulnerability are considered to calculate the total vulnerability. Risk assessment of the Patlekhet landslide has clearly shown that most of the village is in high risk zone. Only zone 2 is in moderate risk zone. Proper investigation of the landslide should be done for adequate mitigative 
measure. The vulnerability should be decreased by improving the house roofs and retrofitting of the houses. National as well as local government should pay attention on this landslide to reduce the risk in this village.

Acknowledgment: We would like to thank program coordinator of Master's in Disaster Risk management, Civil Engineering Department, Pulchowk Campus for encouragement and help during study.

\section{References}

[1] Anbalagan R (1992), Landslide Hazard Evaluation and Zonation Mapping in Mountainous Terrain. Engineering Geology, 32: 269 - 277.

[2] DHM (2016), Department of Hydrology and Meteorology, Government of Nepal.

[3] Nadim F, Kjekstad O, Peduzzi P, Herold C and Jaedicke C (2006), Global landslide and avalanche hotspots. Landslides, 3(2): 159-174

[4] Nagarjan R, Roy A, Kumar RV, Mykherjee A and Khire MV (2000), Landslide hazard susceptibility mapping based on terrain and climate factors for tropical monsoon regions, Bulletin of Engineering Geology and Environment, 58: 275-287.

[5] Saha AK, Gupta RP and Arora MK (2002), GIS-based landslide hazard zonation in the Bhagirathi (Ganga) valley, Himalayas, International Journal of Remote Sensing, 23: 357-369.

[6] Thapa PB and Dhital MR (2000), Landslides and debris flows of 19-21 July 1993 in the Agra Khola watershed of Central Nepal, Journal of Nepal Geological Society. 21:5-20.

[7] Fan Y and Van Den Dool, H (2004), Climate prediction center global monthly soil moisture data set at $0.5^{0}$ resolution for 1948 to present, Jounral of Geophysical Research, 109: D10102.

[8] Nepal Hazard Risk assessment, Part 1: Hazard assessment (2011), Published by Government of Nepal, Asian Disaster Preparedness Center, Norwegian Geotechnical Institute and Centre for International Studies and Cooperation, 114p. 